\title{
Freedom of Association Implementation through Legal Protection for Worker Union in Response to Anti-Union Actions by Employers
}

\author{
Holyness N Singadimedja*, Atip Latipulhayat ${ }^{* *}$, M. Nurdin $\mathrm{S}^{* * *}$ \\ DOI: https://doi.org/10.22304/pjih.v6n3.a6
}

Submitted: September 28, 2019 | Accepted: December 25, 2019

\begin{abstract}
Indonesian labors have rights, either individually or collectively, to associate and to establish organizations. Union is one form of protection and enforcement of workers' normative rights, on conditions that the rights are in line with, and does not conflict with, laws and regulations. The negative attitudes and perceptions of company management towards workers' unions and legal norms still restrict the space for the unions. The situation enables the occurrence of anti-union actions by employers. It becomes increasingly difficult to stop because workers' unions are often trapped by fanaticism that makes them difficult to unite perceptions regarding anti-union actions. This study aims to study the implementation of labor union legal protection by the government facing anti-union actions by employers. The study employed normative juridical, starting with a description of positive laws related to the problem under study. Subsequently, an analysis was carried out by using relevant legal concepts and theories, synchronizing regulations, examining applicable laws in concrete and legal principles as secondary data support. The primary data was obtained through interviews. The results show that the implementation of legal protection for labor unions could not be carried out according to the purpose of the regulation. Therefore, law enforcement on the anti-union actions could not be performed optimally. The National Police, labor inspectors, and civil servants with criminal investigator power were unable to handle anti-union actions. Civil Servants with criminal investigator power in the field of workforce possesses authority based on the law to conduct investigations but mostly, they have not been able to conduct the duty properly. The evidence is the low number of employers that are processed legally based on report to the court.

Keywords: Anti-Worker Union, Right to Organize, Legal Protection
\end{abstract}

\section{Implementasi Hak Berserikat Melalui Perlindungan Hukum bagi Serikat Pekerja dalam Menghadapi Tindakan Anti Serikat Pekerja oleh Pengusaha}

\section{Abstrak}

Pekerja merupakan warga negara Indonesia yang mempunyai hak, baik sebagai individu atau kelompok masyarakat, untuk berserikat dan mendirikan organisasi. Berserikat merupakan salah satu bentuk perlindungan dan penegakan hak normatif pekerja, selama

PADJADJARAN Journal of Law Volume 6 Number 3 Year 2019 [ISSN 2460-1543] [e-ISSN 2442-9325]

* A Lecturer of the Faculty of Law, Universitas Padjadjaran, Jl. Dipatiukur No. 35 Bandung, SH (Universitas Mataram), MH (Universitas Padjadjaran), Dr (Universitas Padjadjaran), holyness@unpad.ac.id

** A Lecturer of the Faculty of Law, Universitas Padjadjaran, Jl. Dipatiukur No. 35 Bandung, SH (Universitas Padjadjaran-Bandung), LLM (Monash University), Ph.D. (Monash University), atiphayat@gmail.com

*** A Lecturer of the Faculty of Law, Universitas Singaperbangsa, Jl. H.S Ronggowaluyo, Karawang, SH (STHPP), MH (Universitas Tarumanagara), Dr (Universitas Pasundan), hmnsingadimedja@gmail.com 
hak untuk berserikat tersebut digunakan sejalan dan tidak bertentangan dengan peraturan perundang-undangan. Sikap dan persepsi negatif manajemen perusahaan terhadap serikat pekerja dan norma hukum yang masih merestriksi ruang gerak serikat pekerja menjadikan tindakan anti serikat pekerja oleh pengusaha memiliki peluang untuk terjadi, hal ini menjadi semakin sulit dihentikan karena diantara serikat pekerja sering terjebak dalam fanatisme sehingga sulit untuk menyatukan persepsi mengenai tindakan anti serikat pekerja. Banyak pelanggaran terhadap ketentuan larangan anti serikat pekerja yang dilakukan pengusaha sehingga penelitian ini bertujuan untuk mengetahui implementasi perlindungan hukum serikat pekerja oleh pemerintah terhadap tindakan anti serikat pekerja oleh pengusaha. Metode penelitian yang digunakan adalah yuridis normatif, diawali dengan inventarisasi hukum positif yang berkaitan dengan masalah yang diteliti, kemudian dilakukan analisis dengan menggunakan konsep dan teori hukum yang relevan, sinkronisasi peraturan, meneliti hukum yang berlaku in concreto dan asas-asas hukum sebagai penunjang data sekunder tersebut ditambah dengan data primer yang diperoleh dengan wawancara. Hasil penelitian menunjukan bahwa implementasi perlindungan hukum bagi Serikat Pekerja belum dapat dilaksanakan sesuai tujuan dibuatnya aturan tersebut, sehingga penegakan hukum terhadap tindakan anti serikat pekerja belum dapat dilaksanakan secara maksimal, Polri, pengawas ketenagakerjaan dan PPNS ketenagakerjaan belum mampu menegakan tindakan anti serikat pekerja, Penyidik Pegawai Negeri Sipil (PPNS) bidang ketenagakerjaan yang diberikan kewenangan oleh undang-undang untuk melakukan penyidikan belum dapat melaksanakan tugasnya dengan baik, hal ini terbukti dengan sangat sedikitnya pengusaha sebagai pelaku tindakan anti serikat pekerja yang diproses hukum mulai dari pelaporan di kepolisian sampai pengadilan.

\section{Kata Kunci: Anti Serikat Pekerja, Hak Berserikat, Perlindungan Hukum}

\section{A. Introduction}

Indonesian workforce development is a part of national development that is carried out based on Pancasila and the 1945 Constitution of the Republic of Indonesia. Workforce development is carried out in the context of the development of both Indonesian people and society as a whole to improve formality, dignity, and self-esteem and to realize prosperous, just, and wealthy society of the workforce. In addition, the development of employment is also to improve the quality of workforce and to improve the protection of workers and their families in accordance with human dignity and self-esteem. The protection of the workforce aims to guarantee the basic rights of workers and to ensure equal opportunities and non-discrimination treatment on any basis in realizing the welfare of workers and their families while considering developments in the progress of the business world. Based on the Preamble of the 1945 Constitution, the general objective of the state of Indonesia is to protect the entire Indonesian people as well as to promote public welfare based on Pancasila for the creation of social justice for all Indonesian people. ${ }^{1}$

1 Tim Redaksi Pustaka Yustisia. Pedoman Terbaru Outsourcing \& Kontrak Kerja: Peraturan 2012 tentang Outsourcing dan Perjanjian Kerja Waktu Tertentu (PKWT), Yogyakarta: Pustaka Yustisia, 2012, p. 8. 
The Law of Workforce is not only concerned with business actors but also pays attention to and protects workers who are socially very weak ${ }^{2}$, compared to the position of employer. The law provides benefits for disadvantaged workers, such as the level of welfare, wage standards, and conditions of work, as stipulated in laws and legislations. It is in line with the meaning of justice according to the provisions of Article 27, Paragraph (2), of the 1945 Constitution that "every citizen has the right to work and a decent living for humanity". It is also in line with Article $28 \mathrm{D}$, Paragraph (2), of the 1945 Constitution, which states "every person has the right to work and to receive fair compensation and treatment, and feasible in a work relationship".

Law Number 13 of 2003 on Workforce is a 'legal umbrella' in the field of industrial relations. It is engineered to maintain order, as well as social control, primarily to provide the basis for the rights of actors in production (of goods and services). In addition, it is also a labor law that is projected to build partnerships. It is stated in the provisions of Article 102 Paragraph (2) and Paragraph (3) of the Law Number 13 of 2003 on Workforce (hereinafter referred to as the Law Number 13 of 2003). This provision is a legal rule that must be obeyed by parties. According to Article 102 Paragraph (3) of Law Number 13 of 2003, entrepreneurs have the function of creating partnerships. It has not provided concrete clarity for industrial communities who are generally lay in understanding legal provisions. Similarly, Article 102 Paragraph (2) of the Law Number 13 of 2003 mentions that, essentially, workers are obliged to carry out work for the sake of sustainable production and to gain company's improvement, in carrying out industrial relations. On the other hand, they have the right as appreciation in carrying out their duties, in addition to carrying out other functions, through labor union to establish the welfare of their families while maintaining order and continuity in the production of goods and services and to develop skills and advance of company.

The state's obligation to guarantee the protection of the the right to assemble is formulated in Article 104, Paragraph (1), of the Law Number 13 of 2003 that every worker/laborer has the right to form and become a member of a labor union. The regulation of the right to form a labor union based on Article 5 Paragraph (1) of Law Number 21 of 2000 on Labor Union is every worker/laborer has the right to form and become a member of a worker/labor union. Workers' Unions are formed by at least ten (10) workers/labors ${ }^{3}$ and can be formed based on the business

$2 \quad$ Krismena Natalina Panjaitan, Pembinaan Karier Ketenagakerjaan dalam Perbankan (Studi Kasus di PT. Bank Negara Indonesia (Persero) Tbk Cabang Karangayu Semarang), Semarang: Universitas Diponegoro, 2010, p. 16.

3 Worker/labor unions are organizations formed from, by, and for workers/laborers both in the company and outside the company, which are free, open, independent, democratic, and responsible for fighting for, defending, and protecting the rights and interests of workers and laborers as well as improve the welfare of workers/laborers and their families (Article 1, Point 1, of Law Number 21 of 2000 on Worker/Labor Unions). 
sector, type of work, or other forms in accordance with the wishes of the worker/laborer. ${ }^{4}$

The principle of freedom of assembly is protected and recognized by legislation. It also includes workers who are union administrators to carry out union activities in working time as stated in Article 29 Paragraph (1) of the Law of Workers Union. They have a right to follow all activities such as national deliberations, work meetings, and activities related union activities. They also have a right to use various facilities to support the smooth operation of workers. ${ }^{5}$

The negative attitudes and perceptions of company management towards workers' unions and legal norms that still restrict the space for unions to make antiunion actions by employers have a chance to occur. This becomes even more difficult to stop because workers' unions are often trapped in fanaticism making them difficult to unify perceptions towards anti-union action ${ }^{6}$

Anti-union actions by employers have taken place since the New Order era. In the 1990s, Marsinah Case became a very well-known case. Marsinah was once a labor activist in Porong, Sidoarjo, who was allegedly kidnapped and killed due to her activities to fight for labor rights. In mid-1993, news about her struggle and sacrifice heavily colored the Indonesian mass media. This tragedy began with the East Java Governor's Decree, which raised East Java's Regional Minimum Wage (UMR) for 1993 by $20 \%$. The company where Marsinah works is PT. Chess Putera Surya objected to comply with the Governor's Decree, triggering demonstrations and strikes among workers. The day after the demonstration, Marsinah disappeared and her whereabouts were unknown, until her body was found three days later. The autopsy show that Marsinah was killed after severe persecution. ${ }^{7}$ The Surabaya District Court convicted all suspects of the murder of Marsinah but the Surabaya High Court ruled that one defendant was acquitted and upheld the previous court's ruling for another defendant two years later. ${ }^{8}$ Marsinah Case happened when Indonesia did not yet have regulations on freedom of association and protection of the right to organize, freedom of civil rights, and protection of human rights.

The issuance of Presidential Decree Number 83 of 1998 on the Ratification of ILO Convention Number 87 on Freedom of Association and Protection of the Right to Organize and enactment of Law Number 21 of 2000 on Worker/Labor Union are weakened by the Police Chief's telegram letter Number Pol STR/227/2001 dated May 31, 2001 and Metro Jaya Police Chief's letter Number Pol: B/674/VIII/1997 dated August 5, 1997. Police clearly prohibits security guards from associating

Pasal 5 ayat (2) Undang-Undang Nomor 21 Tahun 2000 tentang Serikat Pekerja/Serikat Buruh Ibid.

YW. Sunindia dan Ninik Widiyanti, Masalah PHK dan Pemogokan, Jakarta: Bina Aksara, 2003, p. 9.

Nugroho Eko Priamoko, "Union Busting dalam Perspektif Pekerja dan Pengusaha", Prosiding Konferensi ke-2 P2HKI di Universitas Sumatera Utara, Medan, 2017.

8 Dieqy Hasbi Widhana, "Pembunuhan Buruh Marsinah dan Riwayat Kekejian Aparat Orde Baru", tirto.id, accessed on June 17, 2019 at 4:30 p.m. 
because they believe that security guards are the same as the police. ${ }^{9}$ Security guards carry out the functions of the police force, so they can become members of AMSI (Association of Indonesian Security Managers). The consideration that the Security Guard does not have the right to associate is only emphasized on the grounds of state security. There was fear of the National Police as security guards about granting security rights to security guards. Fear of security guards 'support of defending workers/laborers' unions with the union. ${ }^{10}$ Restrictions on the right to form a union by the Security Guard equate the interests of the state with individual interests. This limitation is a violation of human rights that has been outlined in Article 3 of the UN Charter that a person has the right to life, independence, and personal security, should the use of the right to personal security be under or after the use of the right to independence. The right to form a labor union for a security guard is different from an outsourcing system worker.

Some anti-union cases that have been reported and never reached completion end up at police desk on the grounds that there is insufficient evidence or even considered not a crime. They are, among others, the cases of Angkasa Pura I Workers Union, the PT Swadesi Workers Union, and the dismissal of 118 members of the Londre worker union because of striking, the PT PLN, BIS Workers Union, Indosiar Employees Union, Bank Swadesi Workers Union, GSPB-PPBI, and Tony Jack Indonesia Worker Union. ${ }^{11}$ There are still many other violations involving employers. Therefore, the role of law enforcement is needed to prevent and crack down on these anti-union actions.

Based on the description, the study analyzed the concept of the legal protection for workers' union facing workers' union actions by employers and the implementation of workers' union rights facing anti-union actions by employers in industrial relations.

Based on previous observation, no one has yet discussed the implementation of union legal protection from anti-union actions by employers, both in journals and in other scientific works. There are some articles that are correlated with the topic of workers' unions within the past five years, including Nasution (2015), Djou (2017), and Sihombing (2017).

The specific purpose of this paper is to analyze the concept of legal protection and its implementation for workers' unions facing employers' anti-union actions. The writing is expected to contribute ideas and broaden understanding in the field of legal science, especially the development of labor law and human rights as well

\footnotetext{
TURC, ABC, Hak-Hak Serikat Buruh, Jakarta: TURC, 2005, p. 13.

10 The police instructions regarding the prohibition for security guards to become members of a union within DIT BIMMAS POLDA METRO JAYA in http://satpamindonesia.com/?p=257.

11 Lembaga Bantuan Hukum, Kertas Posisi May Day 2012: kebebasan berserikat: Solusi untuk kesejahteraan Buruh, http://www.bantuanhukum.or.id. Downloaded on December 12, 2018.
} 
as benefits the academic community and the community. In addition, it is also expected to contribute to contribute ideas for legal science and the development of labor law and human rights.

This study employed normative juridical research methods. It is analytical descriptive and aims to reveal facts related to the data obtained. The data were in the form of secondary and primary data on various issues related to the topic as well as the applicable laws and regulations associated with legal theories and principles. Data collection techniques were carried out through library research on the provisions in national legislation relating to workers' union protection in Indonesia and relevant and commonly used legal theories. In addition to library data, field data is used as primary data to supplement library research. Field data is needed to draw the legal protection of workers' unions and the responsibilities of the government in practice. The collection of primary data was carried out through interviews with, among others, labor law experts, union administrators, employers' associations, and the ILO Jakarta. Data analysis to evaluate all research results was carried out with qualitative methods descriptively.

\section{B. The Concept of Legal Protection of Workers' Unions facing Anti-Worker Union Actions by Employers}

As a state of law, Indonesia is a material state of law, which is also known as the modern state of law or state of welfare. ${ }^{12}$ The State's objective is the realization of a just and prosperous people both spiritually and materially based on Pancasila. It is also referred to as a "rule of law that has an independent character". ${ }^{13}$ Independence can be seen in the application of the concept and pattern of the rule of law in general, which in Indonesia is adapted to the conditions of the Indonesian people: using the Pancasila benchmark. ${ }^{14}$ In the State of Pancasila, the objective of broader governance is that it is obliged to participate in all sectors of life and livelihood. ${ }^{15}$

One of the goals of the recognition of the rule of law is to protect human rights, meaning that rights and at the same time a freedom of individuals are recognized, respected, and upheld. Recognition and protection of human rights takes first place and can be said to be the objective of the rule of law. One form of legal protection provided by the state is the guarantee of freedom of association and assembly in workers' union/labors' union. Freedom of association and assembly and expressing opinions are basic right of citizens. Based on their dignity, human rights is inherited

\footnotetext{
12 E. Utrecht, Pengantar Hukum Administrasi Negara Indonesia, Bandung: Penerbit FHPM Universitas Padjadjaran, 1960, p. 21-22.

13 Rukmana Amanwinata, Pengaturan dan Batas Implementasi Kemerdekaan Berserikat dan Berkumpul Dalam Pasal 28 UUD 1945, Dissertation, Postgraduate Program at Padjadjaran University, Bandung, 1996, p. 109.

14 Sjahran Basah, Eksistensi dan Tolak Ukur Badan Peradilan Administrasi di Indonesia, $3^{\text {rd }}$ Edition, Bandung: Alumni, 1997, p. 11

15 Ibid.
} 
as human beings and not because of granted by the people and the state. Human rights in the rule of law cannot be separated from order and justice.

Legal protection is the narrow meaning of protection. In this case, the only protection is by law. The protection is also related to the existence of rights and obligations, which are owned by humans as legal subjects in their interactions with fellow humans and environment. As subjects of human law, they have the right and obligation to take legal action. ${ }^{16}$ According to Setiono, legal protection is an act or an effort to protect the public from arbitrary acts by the authorities that are not in accordance with the rule of law, to realize order and peace and to enable humans having their dignity as human beings. ${ }^{17}$

In the formulation of the principles of legal protection in Indonesia, the foundation is Pancasila as an ideology and state philosophy. The conception of legal protection for the people in the West comes from the concepts of rechtsstaat and rule of law. The principle of legal protection against government actions rests and comes from the concept of the recognition and protection of human rights because, historically, in the West, the birth of the concepts of the recognition and protection of human rights is directed to the limitations and placement of community obligations and government. Legal protection is the protection of dignity and the recognition of human rights possessed by legal subjects in a state based on legal protection from arbitrariness. ${ }^{18}$

The concept of human rights is not a new thing for the Indonesian people. One of Indonesia's commitments to respecting and guaranteeing the protection of human rights is contained in the second principle of Pancasila: "Fair and Civilized Humanity", subsequently a number of Articles in the 1945 Constitution and its amendments expressly regulate the guarantee of the protection of human rights. The most important human rights are in the political, social economic and cultural fields. Even the provisions in the 1945 Constitution are formulated three years before the Universal Declaration of Human Rights of the United Nations (Universal of Human Rights) 1948 was promulgated. One of the protections of human rights is the principle of liberty (principle of freedom) in the field of employment relations in Indonesia contained in Article $28 \mathrm{D}$ paragraph (2) Amendments to the 1945 Constitution. In the article, everyone has the right to work and receive compensation and treatment and fair and decent in an employment relationship. This provision implies that every citizen regardless of any differences that exist in a person is entitled to get and do work and receive compensation fairly.

\footnotetext{
16 CST Kansil, op.cit., p. 102.

17 Setiono, Rule of Law (Supermasi Hukum), Surakarta: Masters in Legal Studies, Postgraduate Programs, Universitas Sebelas Maret 2004, hlm.3

18 Philipus M Hadjon, (dkk.), Pengantar Hukum Administrasi Negara, Yogyakarta: Gadjah Mada University Press, 2001, p. 205.
} 
Based on Article 28 E, Paragraph (3), of the Amendment to the 1945 Constitution, every person has the right to freedom of association, assembly, and opinion. It can be interpreted that every citizen regardless of differences in race, sex, religion and others, has the right to be part of an organization and to use that organization for its interests fairly by obtaining protection of freedom of association, assembly, and opinion.

The Article 23 of the Universal Declaration on Human Rights (UDHR) 1948 determines the following. ${ }^{19}$

1. Everyone has the right to work, to free choice of employment, to just and favorable conditions of work and to protection from unemployment.

2. Everyone without any discrimination is entitled to the same salary for the same job.

3. Everyone who works is entitled to fair and beneficial rewards that guarantee a proper existence for human dignity for themselves and their families, and are equipped, when necessary, by other means of social protection,

4. Everyone has the right to form and join workers' unions to protect their interests.

Freedom of association and assembly is contained in ILO Convention Number 87 of 1948 on Freedom of Association and Protection of the Right to Organize. It has been ratified and set forth in Presidential Decree of the Republic of Indonesia Number 83 of 1998. The ILO Convention No. 98 of 1949 on the Right to Organize and Collective Bargaining has been ratified in the Law Number 18 of 1956. Convention Number 87 is intended as a whole to protect freedom of association from possible government interference. Convention Number 98 is intended to encourage the full mechanism of voluntary collective bargaining.

In supporting human rights principles, Rawls, states the following. First, the general principles of justice underlie various moral decisions. Second, the goal of justice lies in the social structure (community), such as social, political, legal, community institutions, including the constitution, private ownership of the means/infrastructure of production, competitive markets that require the cooperation of all parties. Third, the principle of equal freedom for all people (freedom in fighting for legal rights and/or interests), which contains aspects of difference and equality (the principle of social and economic difference) must be regulated to provide greatest benefit for the most disadvantaged including welfare, income and authority, and the principle of equality is fair with opportunity. This means that everyone has the same rights and opportunities to get freedom in accordance with the principles of human rights). ${ }^{20}$

From the description above, the inclusion of human rights formulations in the Constitution shows that there is a legal guarantee and democracy as options in the

\footnotetext{
19 Bahder Johan Nasution, "Fungsi Kebebasan Berserikat bagi Pekerja dalam Hubungan Industrial Pancasila", Jurnal Inovatif, Vol. VIII No. 1, 2015, pp. 100-101.

20 Majda El-Muhtoj. Hak Asasi Manusia Dalam Konstitusi Indonesia, Jakarta: Prenada Media, 2005, p. 66.
} 
government system. They are manifestation of the implementation of human rights. Freedom of association means the right of workers and employers to become members of the organization of their choice and participate in the collective bargaining process. Collective bargaining is potentially a powerful way of enabling coordination between employers' associations and worker unions in setting wages, terms of employment, and other industrial relations matters. Freedom of association guarantees better representation for workers and results in better social participation in the process of good governance and development. The significant role of worker unions in Indonesia has been known for decades, since the rise of anti-colonial nationalist struggles and movements. However, during the New Order regime, freedom of association was suppressed and closely monitored by the ruling parties.

The need for protection of the freedom to form a worker/labor union is also based on the purpose and function of the worker/labor union itself. Basically, the right to freedom of association embodied in the form of worker unions in industrial relations has two main functions. First, it protects workers by contributing to setting minimum standards on wages, occupational health, social security, and working hours for workers. Second, it regulates the working relationship between employers, workers, and the government by setting regulations in the form of Collective Labor Agreement. The aim is to change the role of workers, from originally an object into partners in production process. ${ }^{21}$

The legal regulations of worker union in Indonesia are regulated and formed based on:

1) International Covenant on Economic, Social and Cultural Rights;

2) The 1945 Constitution of the Republic of Indonesia;

3) Universal Declaration on Human Rights Article 20 paragraph (1) and Article 23, Paragraph (4);

4) Law Number 18 of 1956 on the Ratification of ILO Convention Number 98 on the application of the Basic Right to Organize and for Collective Bargaining;

5) Law Number 39 of 1999 on Human Rights;

6) Law Number 21 of 2000 on Worker/Labor Unions;

7) Law Number 13 of 2013 on Workforce;

8) Law Number 2 of 2004 on Settlement of Industrial Relations Disputes;

9) Presidential Decree of the Republic of Indonesia Number 83 of 1998 on the Ratification of the Convention (Number 87) on Freedom of Association and Protection of the Right to Organize;

10) Decree of the Minister of Workforce and Transmigration Number KEP 201/MEN/1999 on the Registration of Worker/Labor Unions

$21 \quad$ Ibid., p. 173. 
11) Decree of the Minister of Workforce and Transmigration Number KEP 16/MEN/2001 on the Procedures for Registration of Worker/Labor Unions.

The Law of Worker Union divides worker/labor unions into a union within the company and a worker/labor union outside the company. Based on the provisions of Article 1 Point 2 of the Law of Worker Union, worker/labor unions in companies are worker/labor unions established by workers/laborers in one company or in several companies. Based on the provisions of Article 1 number 3 of the Law of Worker Union, worker/labor unions outside the company are worker/labor unions established by workers/laborers who work outside the company. Furthermore, the worker union can form a federation of worker/labor unions or confederation of worker/labor unions. Based on the provisions of Article 1 number 4 of the Law of Worker Union, worker/labor union conferences are a union of worker /labor union federations.

Workers in a company can join to form a worker/labor union involving worker/labor unions from several companies into a worker/labor union. Some worker union federations/labor unions can subsequently form worker/labor union confederations.

The essence of worker/labor unions is affirmed in Law Number 21 of 2000. It explains that worker/labor unions are a means to fight for, protect, and defend interests and welfare of workers/laborers and their families and realize harmonious industrial relations, dynamic and fair.

The provision is reaffirmed in General Provisions of the Law Number 21 of 2000 on Worker/Labor Unions and Law Number 13 of 2003 on Labor. It states that a worker/labor union is an organization formed from, by, and for workers of companies and outside companies that are free, open, independent, democratic; and are responsible for fighting for, defending, and protecting the rights and interests of workers/laborers and improving the welfare of workers/laborers and their families. The committee that forms a worker/labor union in establishing a worker/labor union work based on

1) Article 28 of the 1945 Constitution that regulates freedom of association and assembly;

2) Article 5 paragraph (1) of Law Number 21 of 2000 on Worker/Labor Unions stating that every worker/laborer has the right to form and become a member of a Worker/Labor Union.

The implementation of human rights granted by the state to the protection of organizations includes Article 28 Chapter VII concerning Protection of Organizational Rights in the Worker Union Law as follows.

"Siapapun dilarang menghalang-halangi atau memaksa pekerja/buruh untuk membentuk atau tidak membentuk, menjadi pengurus atau tidak menjadi pengurus, menjadi anggota atau tidak menjadi anggota 
dan/atau menjalankan atau tidak menjalankan kegiatan serikat pekerja/serikat buruh dengan cara:

a. melakukan pemutusan hubungan kerja, memberhentikan sementara, menurunkan jabatan, atau melakukan mutasi;

b. tidak membayar atau mengurangi upah pekerja/buruh;

c. melakukan kampanye anti pembentukan serikat pekerja/ serikat buruh."

[Anyone is prohibited from obstructing or forcing workers/laborers to form or not form, become an administrator or not become an administrator, become a member or not become a member and/or run or not carry out worker union activities by:

a. terminating employment, suspending employment, demanding office, or mutating;

b. does not pay or reduce workers' wages;

c. campaign against the formation of worker/labor unions.]

Provisions regarding criminal sanctions are regulated in Article 43 of Chapter XII on Sanctions of Worker Union Laws as follows.

(1) Anyone who blocks or compels workers/laborers as referred to in Article 28, shall be subject to a minimum of 1 (one) year imprisonment and a maximum of 5 (five) years and/or a minimum fine of Rp. 100,000,000.00 (one hundred million rupiah) and a maximum of Rp.500,000,000.00 (five hundred million rupiah).

(2) The criminal act referred to in paragraph (1) constitutes a criminal offense.

The Law of Worker Union does not regulate obligation for workers to seek prior permission from the company before establishing a union/labor union. It is regulated in the Law as a notification after the union/labor union is registered with the labor service local work (Article 18 paragraph (1) Law of Worker Union). If the company continues to pose a threat of Termination of Employment (FLE), when a worker union is formed, this can be reported to the Labor Inspector or the local police.

The use of criminal law in regulating the community, through criminal legislation, is essentially part of policy. Furthermore, the determination of a rational step in conducting a policy cannot be separated from goals of development policy integrally. Thus, efforts to determine any policy, including criminal law policy, is always related and inseparable from the national development goal: to realize prosperity for the people. Criminal law policy is an alternative to criminal policy. Efforts through the penalty path are repressive efforts, which in their implementation contain limitations. Therefore, it needs to be balanced with non- 
penal approach that tends to be a preventive effort. Thus, based on the perspective of criminal politics at a macro and global level, non-penal efforts occupy key and strategic positions in the overall criminal political effort. ${ }^{22}$ This does not mean that the penal effort is not important but the penal effort is a very vital means in the process of law enforcement in tackling crime. The criminal law policy is related to the process of criminal law enforcement as a whole, covering material criminal law policies/substantial, criminal procedural law, and criminal enforcement law.

Crimes generally consist of two types, criminal offenses (rechtsdelicten) and criminal violation (wetsdelicten). The distinction between criminal acts and violations can be concluded from the MvT statement that the distribution is based on the reason that in reality there are acts that are basically despicable and deserve to be convicted, even before they are stated by law. In addition, there are also acts that are against the law and convicted after the law states so. ${ }^{23}$

Differences in crime and violations can also be seen in terms of the impact caused by these actions on the public interest: broad or narrow. A crime is an evil act or behavior that is contrary to the values and norms that have been passed by written law. A violation is an act of violation or a criminal offense that is lighter than the crime and the impact of the crime is broader than the violation then the sanction for the crime is also far heavier than violation.

Related to criminal offenses in the field of workforce, there are two types of criminal offenses: crimes and violations in the field of labor that harm the workers/laborers. The criminal sanctions can be in the form of administrative criminal sanctions, criminal fines, imprisonment, to prison sentences. Provisions for regulation crimes deterring or enforcing the right to freedom of association are not clearly regulated in the Criminal Code. However, the formulation of criminal acts against the independence of people in the Criminal Code can be used to ensnare perpetrators of criminal acts of deprivation of the right to freedom of association. Crimes against the freedom of persons are regulated in Article 335 of the Second Book of the Criminal Code, Chapter XVIII. The Criminal Code does not provide understanding and boundaries regarding "coercion", violence, or unpleasant treatment. It does not stipulate further regarding this matter so that it could be interpreted using scientific interpretation, which requires various literatures such as dictionaries, books, expert statements and jurisprudence. In practice, the application of Article 335 of the Criminal Code by the Supreme Court will emphasize the interpretation of "coercive elements" as the main element that must be present in a series of unpleasant acts. The element of coercion, according to the Supreme Court, is not always translated in the form of physical coercion but can also be in the form of psychological coercion. Law Number 9 of 1998 on Independence Expressing Opinions in Public states that anyone with violence or

Barda Nawawi Arief, Bunga Rampai Kebijakan Hukum Pidana, Jakarta: Kencana, p. 49.

Adami Chazawi, Tindak Pidana Pemalsuan: Tindak Pidana Menyerang Kepentingan Hukum terhadap Kepercayaan Mayarakat mengenai Kebenaran Isi Tulisan dan Berita yang Disampaikan, Rajawali Pers, p.123 
threat of violence obstructs the right of citizens to express their opinions in public who have fulfilled the provisions of this Law shall be sentenced to a maximum imprisonment of 1 (one) year (Article 18). Regarding the provisions referred to, according to Article 144 in conjunction with Article 185 of the Law of Worker Union, employers are prohibited to (1) replace striking workers/laborers with other workers/laborers from outside the company; or (2) provide sanctions or countermeasures of any kind to workers/laborers and officials of labor unions during and after a strike. Furthermore, Article 185 mentions that (1) anyone who violates the provisions referred to in Article 42 paragraph (1) and paragraph (2), Article 68, Article 69 paragraph (2), Article 80, Article 82, Article 90 paragraph (1), Article 143, and Article 160 paragraphs (4) and (7), are subject to a minimum of 1 (one) prison sentence; and (2) the criminal act referred to in paragraph (1) is a crime. "

Criminal provisions in Law Number 9 of 1998 to guarantee and provide protection for the freedom of freedom of every citizen to express opinions, thoughts, ideas both oral and written in public, can also be used by law enforcement agencies to handle violations of the provisions of Article 28 of the Law of Worker Union.

\section{Implementing Legal Protection for Worker Union Facing Anti-Worker Union Actions by Employers}

Legal protection of the right to freedom of association for workers is not only limited to the protection of the rights of workers to form or become members of worker unions but the more substantial is the protection of union rights. On the one hand, it must be recognized that the freedom of workers to form worker unions in the level of legal policies and their applications has been running well, which is easily proven for workers to form worker unions both at the company level and outside the company, including forming a worker Union Federation and a worker Union Confederation. On the other hand, after the union was formed, recognition and respect for the rights of the union itself has been ignored. The rights of unions are more substantive both in the context of protecting workers' rights and improving welfare as well as in the political struggle of worker unions in influencing public policies in the form of laws and regulations, setting minimum wages, and other labor-related policies. Several criminal cases of freedom of association occurred at PT King Jim Indonesia, Pasuruan, East Java. This case is the first time in Indonesia that is processed to the court and has permanent legal force.

In the current reform era, after the enactment of Law Number 21 of 2000, workers are given the freedom to form or form unions. This opportunity was fully utilized by workers/laborers to form and establish unions, based on the results of verification conducted by the Ministry of Labor in 2017, there are 14 confederation 
of unions, 120 federation of unions with 2.7 million members, down from 3.4 million. ${ }^{24}$

The large number of worker unions established in Indonesia, on the one hand is proof of the functioning of some of the rights of freedom of association but not in the full sense. It also needs to see the fulfillment of rights of union: is there an opportunity for union officials to carry out organizational activities at work, is the union involved in wage policies in the company, how much is the bargaining position of the union in conducting dialogue and negotiations with employers and the government, etc.

The practice of anti-union action is a practice in which a company or employer tries to stop the activities of a worker union in the area of its company. The efforts take various forms using a variety of methods and reasons, from using legal, illegal, and even hiring consultants to carry out anti-union practices. ${ }^{25}$ According to Karsona, this anti-union practice is increasing due to omissions by officials or agencies who are supposed to maintain and oversee the implementation of the right of association for workers guaranteed by the constitution and Law Number 21 of 2000 on Worker/Labor Unions. Article 28 mentions that anyone is prohibited from obstructing or forcing workers/laborers to form or not form, be an administrator or not become an administrator, become a member or not become a member, and/or run or not carry out activities of a worker/labor union by

1) terminating employment, suspending employment, demanding office, or mutating;

2) not pay or reduce the wages of workers/laborers;

3) intimidating in any form;

4) carry out campaigns against the formation of worker/labor unions.

Karsona also stated that anti-union practices have two basic forms. First, companies and employers try to prevent workers from building or joining worker unions. This action is taken so that company is free to exploit without any control from the union. Second, companies and employers try to weaken the power of existing worker unions. Corporate sanctions against union officials and members and intimidation and discriminatory actions are common actions to weaken worker unions. The fundamental reason why companies and employers take anti-union actions is that they consider union to be a bad influence on business continuity. Unions 'demands for living wages, healthy working conditions and safety, and improvement of workers' welfare are detrimental to the company, because the company can no longer collect maximum profits at the expense of workers. In short, the existence of worker unions disrupts the freedom of companies and

\footnotetext{
24 Data source from the Director of Industrial Relations Development, Ministry of Manpower and Transmigration of the Republic of Indonesia, 15 November 2018. 
employers to pay workers the lowest possible wages and neglects the fate of the workers. $^{26}$

The ways or practices of anti-union that often occur include (1) obstructing workers from joining the union, (2) intimidation, (3) transferring management or union members, (4) warning letter, (5) suspension, (6) termination of employment, (7) forming a puppet union or a rival union (yellow union), (8) forming counter officials in the same union, (9) refusing to be consulted about mutual employment agreement, (10) promotions that are detrimental, (11) criminalization, (12) pitting laborers, (13) anti-union doctrine is also studied specifically by employers, (14) hiring thugs, (15) privatization of state-owned enterprises, (16) hiring consultant services, and (17) bribing law enforcement officers. ${ }^{27}$

Within the framework of the criminal justice system, the role of law enforcement officials, particularly investigators, is very strategic. Investigators are the main gateway to the start of the task of finding material truth because the process of investigating the truth began to be implemented. During this wide scope of duties and responsibilities of investigators in the law enforcement system in Indonesia, leaving many problems, not only related to the many institutions that are given the authority to investigate a crime, but also there are still overlapping investigative authority between several institutions. As a result, inter-investigative institutions appear the impression of lack of coordination and synergy that can have an impact on the reduced credibility of law enforcement institutions in the eyes of the public. ${ }^{28}$

Giving the authority to carry out investigative tasks to civil servants with criminal investigator power, on the one hand, will certainly make it easier to disclose a crime considering the many obstacles faced by the police in conducting investigations, such as the quality and quantity of human resources, supporting infrastructure, and budget. However, on the other hand, many investigating institutions have the potential to overlap each other. It is especially when investigating institution puts forward sectoral egos, which can lead to obstruction of the law enforcement process. Therefore, to anticipate the emergence of asynchronous conduct in carrying out investigative tasks, particularly between police investigators and civil servants with criminal investigator power, Criminal Procedure Code has regulated the position of the two institutions. According to Article 7 Paragraph (2) of the Criminal Procedure Code, the Investigator as referred to in Article 6 paragraph (1) letter b (PPNS) has the authority in accordance with the law on which each legal basis is based and in carrying out its duties is under the

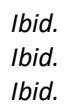


coordination and supervision of the investigator in Article 6 paragraph (1) letter a (police).

To investigate anti-union crime, it is necessary to check whether the events occurred or were carried out with the aim of deterring workers to form, being administrator of, and being member of a union.

Differences in perceptions of the understanding and limits of anti-union actions will ultimately affect their implementation. In the perspective of the legal system, rules regarding anti-union actions are a component of the legal substance, while perceptions regarding these regulations are a component of legal culture. The component of this legal culture greatly influences how the law works. ${ }^{29}$

Regarding anti-union actions as a concept, workers and employers have different perceptions. It can be said that the difference in perception is natural, because workers and employers have different positions and interests, but this is not the case when viewed from a positivist legal point of view. This point of view sees the law as a positive principle generally accepted in abstracto at a certain place and time. ${ }^{30}$ In other words, the law is identified with a written regulation issued by the government, in this case what is meant by anti-union action is what has been formulated in the regulation, there must be no other perception.

It is different from the point of view that sees law in a broader perspective, which sees law as a mental construction that is relative, pluralistic, diverse, intangible, local, specific, built through the experience of human life starting from personal life, family, community, nation, countries to between countries. In other words, each individual or collective can have interpretations of their own laws. In this case, both workers and employers can have their own interpretations of the concept of anti-union action.

Cases of violations of freedom of association in the company actually occur a lot but very little is reported criminally. What appears is a dispute over industrial relations. The following are some cases of violations of freedom of association. ${ }^{31}$

\section{1) The practice of suppressing worker union at PT Wismatata Eltra Jaya, Bekasi Regency}

The case covers the termination of employment of four union officials by PT Wismatata Eltra Jaya, Bekasi Regency due to a demonstration of normative rights in the form of overtime pay and social security that were not fulfilled by the company in 2013. Four core management of the union (a secretary, a general chairperson, and two field heads) were transferred to termination of employment. The employer asks the worker to stop the action. The workers try to do a bipartite but

\footnotetext{
29 See comparison with: Lawrence M. Friedman, Sistem Hukum - Perspektif Ilmu Sosial, terjemahan M. Khozim, New York: Russel Sage Foundation, 1975, pp. 16-17.

30 Erlyn Indarti, Diskresi dan Paradigma - Sebuah Telaah Filsafat Hukum, Pidato Pengukuhan Guru Besar Filsafat Hukum UNDIP, Semarang, November 4, 2017, p. 21

31 Trade Union Right Centre, Kebebasan Berserikat Jalan di Tempat, Jakarta: September 1, 2008
} 
are unsuccessful. Finally, the worker makes a request for mediation and reports to the police. ${ }^{32}$

\section{2) The practice of suppressing worker union at PT SUNGWON, Karawang Regency}

The case covers the termination of employment of a union official by PT SUNGWON, Karawang, to the PUK secretary as the coordinator of employee wage negotiations for reason of efficiency. In 2018, the worker is considered to be a union administrator responsible for workers' demonstrations causing a lot of harm to the company. The company dismissed the Secretary of the PUK on the grounds of efficiency before issued a suspension letter. Workers and the district level worker union tried to do a bipartite to resolve workers' rights. Several demonstrations were held to the company. The workers reported the company to the police and on January 10, 2019, peace was made between workers and employers. The worker was dismissed with severance pay three times of the PMTK. $^{33}$

\section{3) The practice of suppressing worker unions at PT. Batam City UNISEM}

The case covers the termination of employment of 89 workers and union officials by PT Batam City UNISEM. Based on the results of interviews, the company, in 2011, for reasons of efficiency, sacked 3 union unit management company units and 8 employees. As a result of the dismissal, there was anxiety among the workers so that the bipartite was conducted. The company offered some money but the workers refused because they wanted to continue working. The Workforce Office suggested to re-hire workers but the company refused. Before a lawsuit to the Industrial Relation Court, the company has first filed a lawsuit against the workers with material claims of loss suffered by the employer during the workers' rally for about Rp6,000,000,000. The employer also in his lawsuit requested a confiscation (conservator beslag) against the workers' homes. The verdict from the court is not able to accept PT UNISEM because the dispute is labor disputes. They must be resolved through the Industrial Relations Court in Tanjung Pinang District Court. Upon the decision of the court, the company subsequently sacked 8 union officials and 81 employees who are members of the union on the grounds of efficiency. ${ }^{34}$

\section{4) The Case of Reduction of Worker Union in PT DNP Indonesia Jakarta}

PT DNP Indonesia East Jakarta unilaterally dismissed and sued five Worker Union Managers at the Industrial Relations Court for mobilizing workers to stage a demonstration demanding 2014 wage adjustments. The workers report that the company has taken anti-union action and the company reports that workers have done damage during a demonstration. The employer and worker finally made

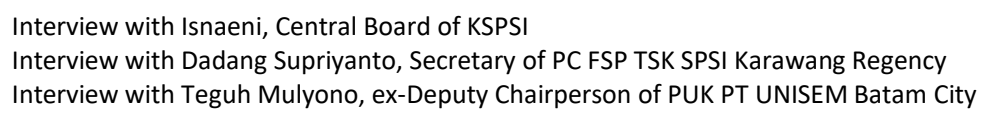


peace and revocation of each report. Then the Company sued five union officials in the Industrial Relations Court with a layoff dispute suit. ${ }^{35}$

There are many more cases of violations of freedom of association that occur and are not revealed. The ILO Geneva Committee of Freedom of Union notes that the number of cases of violations of freedom of association in Indonesia that have been reported to the ILO until 2017 has reached sixteen cases. The Jakarta Office of ILO received copies of reports or complaints of violations of freedom of association, in 2017 around 70 cases. $^{36}$

The presence of worker unions is a full right of workers. It is even considered a basic right of workers in the Workforce Law as a basic right. Its presence must be facilitated, so that the act of obstructing the establishment of worker unions is a form of suppressing worker unions.

It was further conveyed that the concept of anti-union action was often misused with mutual recriminations. An employer could suddenly be complained of doing anti-union action even though the elements were not necessarily fulfilled. Misuse of the concept that should provide this protection is detrimental to employers. Some examples of cases of reporting anti-union actions by employers that are not granted by the judge as follows.

1. Decision of the Supreme Court in the case of Judicial Review in case Number 089PK/Pdt.Sus/2008. This case concerns a request for dismissal filed by the employer because the worker has incited a colleague. A worker who is also a union manager argues that he was dismissed because of his position as a union administrator, and the employer intends to obstruct worker union activities. The court then considered that the worker was proven to have instigated his colleague, so that the request for dismissal was then granted.

2. Decision of the Industrial Relations Court at the Bandung District Court in case Number 19/G/2011/PHI.PN.BDG. In this case, the employer submits a request for dismissal from a worker who serves as a union administrator. This request was submitted because the worker concerned intimidated his coworker. In his defense, the employee argued that the dismissal was carried out because of his position as a union manager and the employer intended to obstruct the activities of the union. The court finally decided that the workers were proven guilty of violations as argued. Therefore, the request for dismissal was granted. Based on the court's decision over the Apindo management, Djimanto, judged that disputes between employers and workers or worker unions were in accordance with Law Number 2 of 2004 on the Settlement of Industrial Relations Disputes as a civil dispute. Therefore, anti-union action should not be a criminal offense because it involves civil relations.

35 Interview with Fredy Sembiring, Chairperson of the PUK Federation of Printing, Publishing and Information Media Trade Unions KSPSI PT. DNP Indonesia, South Jakarta, November 2, 2018

36 Interview with Soeharjono (National Project Coordinator ILO/ACTRAV Jakarta), in Jakarta, October 15, 2018 
In practice, if unions work together with groups outside of workers, even though they have a high potential for bearing, but often collide with employer repression and are a reason for companies to take minor actions that harm workers or union officials such as mutations and layoffs. One thing that can actually be done is to make the labor inspector's role effective so that anti-union action does not take place. It's just that from the companies that were used as a study in this study, both workers and company management said there was no labor inspection. The visit from the Office of Workforce is only brief and only looks at the physical condition of the company. The Office of Workforce says that labor inspection has not been optimal because of the limited number of existing labor inspectors, for example the number of supervisors that is very lacking, and even then only supervisors that are general and not supervisors are have special expertise. ${ }^{37}$ Many cases that clearly constitute labor crimes in Indonesia are known based on reports received by the Office of Workforce but Employee Inspection Employees have less role in carrying out law enforcement efforts (criminalizing) labor crimes. ${ }^{38}$

The use of a penal tool (criminal law) in criminal policy has two central problems, namely what actually acts as a crime and what sanctions should be used or imposed on the offender. The first central problem is often called criminalization. According to Soekanto, criminalization is an act or determination of the authorities regarding certain acts which are considered by the community or groups of people to be criminal acts or make an act criminal and therefore can be convicted by the government by working on the name. Criminalization can also be interpreted as the process of determining a person's actions as acts that can be convicted or a process of raising an act that was not originally a criminal act into an act that can be convicted.

In practice, the activeness of workers in worker union activities is the first weapon used to fight for workers' rights and to elevate their positions in line with employers. The methods adopted through worker unions are usually carried out by submitting demands on employers when negotiating collective work agreements, strikes to fight for workers' rights, and holding demonstrations and statements of solidarity with fellow workers who have been pressured and or mistreated by employers. Actions that prohibit workers/laborers from forming worker unions in various ways are acts which are detrimental to workers/laborers because their rights are not fulfilled. It is appropriate for the Government of Indonesia to overcome the problem of freedom of association of workers/laborers by issuing a criminal law policy, namely the Law Number 21 of 2000 on Worker/Labor Union (State Gazette of the Republic of Indonesia of 2000 Number 131). The Law

Interview with Soeroto Head of Office of Workforce of Karawang, October 23, 2018

38 Parningotan Malau, Penegakan Hukum Perlindungan Pekerja/Buruh dalam Tindak Pidana ketenagakerjaan, Prosiding Konferensi ke-2 P3HKI di Medan, 2017, p. 113 
regulates various aspects of worker/labor union, including regulating the protection of the freedom to form worker/labor union.

Industrial relations in Indonesia are based on the Pancasila industrial relations. It is the relationship between the actors in the production process of goods and services (workers/laborers, entrepreneurs, and the government) based on values that are manifestations of the overall values of the Pancasila precepts and the 1945 Constitution that grow and developing above the national personality and national culture of Indonesia. In accordance with the principles adopted in the Pancasila industrial relations, industrial relations aim to (a) create calm or peace of work and business calm; (b) increase production; and (c) increasing the welfare of workers/laborers and their degrees in accordance with human dignity, therefore Pancasila industrial relations must be carried out according to tri-partnerships. They are partnerships in responsibility, in production, and in profit. Indonesia is a state of law and one characteristic of the rule of law is the recognition of human rights. As a legal state, based on Pancasila, it must reflect the existence of the soul of the nation and animate, and underlie the applicable legal regulations in order to realize public welfare and order. It contains juridical consequences that every citizen and state official, where all his actions must be based on law, however criminal action is expected to be the last act after other legal actions have been taken as ultimum remidium in labor law as a form of implementing law enforcement.

\section{Conclusion}

In order to achieve the welfare of the people, especially workers and to prevent criminal acts against workers, the government has made a policy to use the means of "penal" code (criminal law). It is intended to be a concept of legal protection for worker unions by issuing laws and regulations concerning labor. The laws and the regulation regulate and protects workers' rights and obligations by including criminal provisions, whether in the form of administrative criminal, fines, imprisonment, or imprisonment. It is expected that this will cause a deterrent effect and become one of the efforts to overcome the action criminal in the field of work force.

In terms of the implementation of legal protection by the government facing anti-worker union actions by employers in Pancasila Industrial Relations, the Article 28 and 48 of the Law of Worker Union cannot be implemented according to the purpose of the regulation. Both workers and employers have different perceptions of the implementation of the article. The enforcement of the law on anti-union actions has not been able to be implemented maximally. The National Police, labor inspectors, and Civil Servants with Criminal Investigator power were unable to handle anti-union actions. Civil Servants with Criminal Investigator power in the field of workforce possesses authority based on the law to conduct investigations but mostly, they have not been able to conduct the duty properly. The evidence is 
the low number of employers that are processed legally based on report to the court.

\section{References}

\section{Books}

Adami Chazawi, Tindak Pidana Pemalsuan: Tindak Pidana Menyerang Kepentingan Hukum terhadap Kepercayaan Mayarakat mengenai Kebenaran Isi Tulisan dan Berita yang Disampaikan, Rajawali Pers, Jakarta, 2016.

Adrian Sutendi, Hukum Perburuhan, Penerbit Sinar Grafika, Jakarta, 2009.

Barda Nawawi Arief, Bunga Rampai Kebijakan Hukum Pidana, Kencana, Jakarta, 2017.

E. Utrecht, Pengantar Hukum Administrasi Negara Indonesia, Penerbit FHPM Universitas Padjadjaran, Bandung, 1960.

Krismena Natalina Panjaitan, Pembinaan Karier Ketenagakerjaan dalam Perbankan (Studi Kasus di PT. Bank Negara Indonesia (Persero) Tbk Cabang Karangayu Semarang), Universitas Diponegoro, Semarang, 2010.

Lawrence M. Friedman, Sistem Hukum - Perspektif IImu Sosial, terjemahan M. Khozim, Russel Sage Foundation, New York, 1975.

Majda El-Muhtoj, Hak Asasi Manusia Dalam Konstitusi Indonesia, Prenada Media, Jakarta, 2005.

Philipus M. Hadjon, (dkk.), Pengantar Hukum Administrasi Negara, Gadjah Mada University Press, Yogyakarta, 2001.

Setiono, Rule of Law (Supermasi Hukum), Magister Ilmu Hukum Program Pascasarjana Universitas Sebelas Maret, Surakarta, 2004.

Sjahran Basah, Eksistensi dan Tolok Ukur Badan Peradilan Administrasi di Indonesia, Cetakan Ketiga, Alumni, Bandung, 1997.

Soerjono Soekanto, Kriminologi: Suatu Pengantar, Ghalia Indonesia, Jakarta, 1981.

Tim Redaksi Pustaka Yustisia, Pedoman Terbaru Outsourcing \& Kontrak Kerja: Peraturan 2012 Tentang Outsourcing dan Perjanjian Kerja Waktu Tertentu (PKWT), Pustaka Yustisia: Yogyakarta, 2012.

Trade Union Right Centre, Kebebasan Berserikat Jalan di Tempat, TURC, Jakarta, 2008. , Hak-Hak Serikat Buruh, TURC, Jakarta, 2005.

YW. Sunindia and Ninik Widiyanti, Masalah PHK dan Pemogokan, Bina Aksara, Jakarta, 2003.

\section{Other Documents}

Bahder Johan Nasution, "Fungsi Kebebasan Berserikat bagi Pekerja dalam Hubungan Industrial Pancasila", Jurnal Inovatif, Vol. VIII, No. 1, 2015. 
Dieqy Hasbi Widhana, "Pembunuhan Buruh Marsinah dan Riwayat Kekejian Aparat Orde Baru", tirto.id, accessed on June 17, 2019.

Djoko Heroe S. "Eksistensi Hukum Ketenagakerjaan Dalam Menciptakan Hubungan Kemitraan antara Pekerja Dengan Pengusaha", Dissertation, Postgraduate, Faculty of Law, Universitas Brawijaya, 2006.

Erlyn Indarti, Diskresi dan Paradigma - Sebuah Telaah Filsafat Hukum, Speech of Inauguration of Professor of Law Philosophy of UNDIP, Semarang, November 4, 2017.

Lembaga Bantuan Hukum, Kertas Posisi May Day 2012: kebebasan berserikat: Solusi untuk kesejahteraan Buruh, downloaded from http://www.bantuanhukum.or.id.

Nugroho Eko Priamoko, "Union Busting dalam Perspektif Pekerja dan Pengusaha", Prosiding Konferensi ke-2 P2HKI at the Universitas Sumatera Utara, Medan, 2017.

Parningotan Malau, Penegakan Hukum Perlindungan Pekerja/Buruh dalam Tindak Pidana ketenagakerjaan, Prosiding Konferensi ke-2 P3HKI, Medan, 2017.

Petunjuk polisi tentang larangan bagi anggota satpam untuk menjadi anggota serikat pekerja dalam DIT BIMMAS POLDA METRO JAYA in http://satpamindonesia.com/?p=257

Rukmana Amanwinata, "Pengaturan dan Batas Implementasi Kemerdekaan Berserikat dan Berkumpul Dalam Pasal 28 UUD 1945", Dissertation, Postgraduate Program at Padjadjaran University, Bandung, 1996.

\section{Law Documents}

The 1945 Constitution of the Republic of Indonesia [Undang-Undang Dasar Negara Republik Indonesia Tahun 1945]

Law Number 39 of 1999 on Human Rights [Undang-Undang Nomor 39 Tahun 1999 tentang Hak Asasi Manusia]

Law Number 21 of 2000 on Worker/Labor Unions [Undang-Undang Nomor 21 Tahun 2000 tentang Serikat Pekerja/Serikat Buruh]

Law Number 13 of 2003 on Workforce [Undang-Undang Nomor 13 Tahun 2003 tentang Ketenagakerjaan]

Law Number 23 of 2003 on the Ratification of the ILO Convention Number 81 on Labor Inspection in Industry Commerce [Undang-Undang Nomor 23 Tahun 2003 tentang Pengesahan ILO Convention Number 81 Labour Inspection In Industry Commerce (Konstitusi ILO Nomor 81 mengenai Pengawasan Ketenagakerjaan dalam Industri dan Perdagangan)]

The Convention of International Labor Organization (ILO) Number 87 of 1949 on Freedom of Association and Protection of the Right to Organize [Konvensi International Labour Organization (ILO) Nomor 87 tahun 1949 tentang Kebebasan Berserikat dan Perlindungan Atas Hak Berorganisasi] 
Freedom of Association Implementation through Legal Protection for Worker Union in Response to Anti-Union Actions by Employers

The Convention of International Labor Organization (ILO) Number 98 of 1949 on the Right to Organize and Collective Bargaining [Konvensi International Labour Organization (ILO) Nomor 98 tahun 1949 tentang Hak Berorganisasi dan Perundingan Bersama] 